\title{
Effect of Using Picture Series on the Indonesian EFL Students' Writing Ability across Learning Styles
}

\author{
Rahayu Hesthi Wening \\ Graduate Program in ELT, Universitas Negeri Malang, East Java, Indonesia \\ Bambang Yudi Cahyono \\ Universitas Negeri Malang, East Java, Indonesia \\ Emalia Iragiliati \\ Universitas Negeri Malang, East Java, Indonesia
}

\begin{abstract}
Picture series are visual media which are potential to help EFL students learn to write. Therefore, we intended to investigate the effect of using picture series on Indonesian EFL students' writing ability across learning styles. The effect of using picture series on students' ability in writing recount texts was verified first and the effect of picture series across the students' learning styles was examined consecutively. To achieve the goals, a quasi-experimental design was implemented. The subjects of this study were 2 classes of students of the Junior High School 2 at Kawunganten, Cilacap, Central Java. We administered writing tests, distributed a learning style questionnaire, and asked the students to complete an opinion questionnaire. The findings revealed that the students who were taught using picture series had better writing ability than those who were taught without using picture series. The findings also showed that by using picture series the visual students had better writing ability than the auditory students. Furthermore, the students had positive opinion towards the use of picture series. It is suggested that EFL teachers use picture series as one strategy in teaching writing and future researchers conduct further research dealing with the use of picture series.
\end{abstract}

Keywords: picture series, writing ability, learning styles, Indonesian EFL students

\section{INTRODUCTION}

Writing, in addition to listening, speaking, and reading, is one of language skills which is taught as one of the compulsory subjects to the students of junior high school in Indonesia. Writing is a productive skill that plays an important role in learning a language. By using written English, English as a foreign language (EFL) students can deliver messages to the readers across places and times (Brown, 2007; Harmer, 2004). In addition, based on the 2013 Indonesian Curriculum, the students of junior high school should be able to identify social function, generic structure, and linguistic feature of texts. They are expected to produce short spoken and written text (Kemdikbud, 2016). It means that writing has an important role in English teaching and learning.

Unfortunately, most of the junior high school students thought that writing is the most difficult skill to be mastered (Pertiwi, 2016). According to Pertiwi (2016), the difficulty lies not only in generating and organizing the ideas, but also in vocabulary, grammar, and mechanics use. As a consequence, the students feel bored and have less motivation in writing. This implies that the teachers of junior high school students should be creative in the teaching of writing.

One of the ways considered effective in teaching writing is by using instructional media. Smaldino, Lowther, and Russel (2009) state that the purpose of instructional media is to facilitate communication and learning. If instructional media are used, students will be more interested and enthusiastic in joining the teaching and learning process. There are many kinds of instructional media that can be used in the teaching and learning process. According to Samjaya (2012), there are three types of instructional media, namely audio (instructional media which can be heard such as radios and tape recorders), visual (instructional media which can be seen such as pictures, photographs, drawings, and charts), and audiovisual (instructional media which can be heard and seen such as videos and televisions). 
Visual media in particular are considered as an effective means to support learning since students learn most through the sense of sight (Chee \& Wong, 2003). As a kind of visual media, pictures are useful for the teaching of writing. The use of pictures as visual media in the teaching and learning process is intended to make teaching and learning process more effective so that the students' writing ability can be improved. Wright (1989) states that pictures make a particularly powerful contribution to both the content and the process of language learning.

There are a lot of types of picture that can be used as an aid in teaching writing, such as single picture, picture series, diagrams, tables, maps, and charts (Raimes, 1983). For example, picture series can help the students generate ideas. Fachrurrazy (2012) mentioned that pictures or photographs are useful to teach descriptive texts (e.g., picture of objects), procedure text (e.g. picture of ingredients), and recount text (e.g., picture of events). In selecting pictures that will be used in their classroom, teachers should make appropriate choices between the sorts of picture that are preferred and those that are most effective. Pictures which have good arrangement, balance, colour, legibility, and appeal will be good visual media in teaching and learning process (Smaldino, et al., 2009).

The picture series used in this study were the students' own photographs. The students' own photographs were good media for learning to write recount texts since these photographs could tell the students' own experience. A recount text is a text that tells what happened and it has orientation, series of events, and reorientation as the generic structure (Agustien, Anugerahwati, \& Wachidah, 2004). In this study, we conducted Genre-Based Approach (GBA) to teach writing by using picture series. There are four steps in GBA: Building Knowledge of the Field (BKoF), Modelling of the Text (MoT), Joint Construction of the Text (JCoT), and Independent Construction of the Text (ICoT).

However, in the teaching and learning process, the students learn in many different ways. The students learn best by seeing the value and importance of the information presented in the classroom since they have their own learning styles. Celce-Murcia (2001) defines learning styles as the general approach (e.g., global or analytic, auditory or visual) that the students use in acquiring a new language or learning any other subject. We intended to examine the effect of the use of picture series on the students' ability in writing recount texts across learning styles. The learning styles investigated in this study were limited into visual and auditory learning styles.

Previous studies have reported the implementation of picture series to teach writing. Asrifan (2015), Guitterez, Puello, and Galvis (2015), Nirmala (2013), and Yuliarsih (2016) conducted experimental research by using picture series in teaching writing and revealed the effectiveness of picture series in teaching writing. However, their findings did not explore more on the other variables, such as learning styles. To the best of our knowledge, there is limited research regarding the presence of interaction between the use of teaching media, especially picture series, and the students' learning styles. Thus, this study had two objectives. First, it investigates the effect of using picture series on the EFL students' ability in writing recount texts, and then it examines the effect of the use of picture series across the students' learning styles.

\section{METHOD}

To achieve the objectives of the study, we implemented a quasi-experimental design at the second semester of academic year 2016/2017. This study involved 2 classes of grade eight students of Junior High School 2 at Kawunganten, Cilacap, Central Java, Indonesia. There were 32 students in the experimental group and 32 students in the control group. Both of the groups received the same treatment, except the teaching media. The experimental group was taught using picture series, while the control group was taught without using picture series. We collected the data by conducting the experiment in eight meetings including the pretest and posttest.

Some instruments were used to collect the data in this study. The main instruments were in the form of writing tests. The writing tests were conducted twice, before (pretest) and after (posttest) the treatment. The pretest was used to check the homogeneity between the experimental and the control groups before the treatment and the posttest was used to test the hypotheses. We developed the writing prompts and tried them out before being used. The students' written products were scored by using analytical scoring rubric in terms of content, organization, vocabulary, grammar, and mechanics by using scoring rubric adapted from Jacobs, Zinkgraf, Wormuth, Hartfiel, at al (1981). To avoid bias, the writing tests were scored by two raters. The interrater reliability revealed that the writing tests had high reliability as shown by the Cronbach alpha coefficient. 
The second instrument was a learning styles questionnaire which was administered to classify the students based on their learning style. This instrument was adapted from DePorter, Reardon, and Singer-Nourie (1999). We tried out the instrument to check the reliability. The results showed that all the items of the questionnaire were valid and the results of the Cronbach alpha test also showed that the instrument was highly reliable. The last instrument employed in this study was the students' opinion questionnaire which was functioned to see their opinion towards the use of picture series.

\section{RESUlts}

The results of the pretest and posttest given to the experimental and control groups are shown in Table 1.

Table1. Descriptive Statistics Data of the Pretest and Posttest

\begin{tabular}{|l|l|l|l|l|}
\hline \multirow{2}{*}{ Descriptive Statistics } & \multicolumn{2}{|c|}{ Pretest } & \multicolumn{2}{c|}{ Posttest } \\
\cline { 2 - 5 } & Experimental Group & Control Group & Experimental Group & Control Group \\
\hline N & 32 & 32 & 32 & 32 \\
\hline Mean & 64.88 & 65.38 & 75.17 & 71.11 \\
\hline SD & 4.20 & 4.19 & 4.45 & 4.69 \\
\hline
\end{tabular}

Table1 shows that the experimental group (64.88) had a lower mean than the control group (65.38). However, after the treatment was given, the experimental group (75.17) had a higher mean than the control group (71.11). Even though the mean was different between the experimental and control groups, an analysis to investigate the significance needs to be conducted by testing the hypotheses.

Before testing the hypotheses, the results of pretest were analyzed to see whether or not the data fulfilled the statistical assumptions. The statistical assumptions covered the normality and homogeneity test. Normality test was used to measure the distribution of data so as to see whether it was normal or not. This test was calculated by using Kolmogorov-Smirnov test. The results of normality test of the pretest can be seen in Table 2 .

Table2. Normality Test

\begin{tabular}{|l|l|l|l|l|}
\hline Group & $\mathbf{N}$ & Kolmogorov-Smirnov Z & Sig & Description \\
\hline Experimental & 32 & 1.256 & 0.085 & Normal \\
\hline Control & 32 & 0.618 & 0.839 & Normal \\
\hline
\end{tabular}

From the calculation, it was found that the obtained significant value of the experimental group was 0.085 and the control group was 0.839 . Since 0.085 and 0.839 were more than 0.05 , the data of pretest in the experimental and control groups were normally distributed.

Furthermore, the homogeneity test was used to see whether or not the variances of the groups were homogenous in order to obtain information equality between the experimental and control groups before the treatment was given. This test was calculated by using the Levene's test. The result of homogeneity test is described in table 3.

Table3. Homogeneity Test

\begin{tabular}{|l|l|l|l|l|}
\hline Group & N & Levene's Statistic & Sig & Description \\
\cline { 1 - 2 } Experimental & 32 & \multirow{2}{*}{0.447} & 0.506 & \multirow{2}{*}{ Homogeneous } \\
\hline Control & 32 & & & \\
\hline
\end{tabular}

The test shows that the obtained significant value of homogeneity test between the experimental and control groups was 0.506. Since 0.506 was higher than 0.05 , it meant that the experimental and the control groups were homogeneous.

Since the statistical assumptions of normality and homogeneity were fulfilled, the parametric statistical analysis was administered to test the hypotheses. The main data of the hypotheses testing were taken from the students' posttest scores. The hypotheses testing in this study was investigated by using independent $t$-test to see the effectiveness.

The first hypothesis was about the effectiveness of picture series on the students' writing ability in writing recount texts. It was analyzed by using independent $t$-test and the result is shown in Table 4.

Table4. Results of the Independent t-test between the Experimental and Control Groups

\begin{tabular}{|l|l|l|l|l|l|l|}
\hline \multicolumn{1}{|c|}{ Group } & N & Mean & t & df & Sig. & Description \\
\cline { 1 - 5 } Experimental & 32 & 75.17 & \multirow{2}{*}{3.555} & 62 & \multirow{2}{*}{0.001} & \multirow{2}{*}{ Significant Difference } \\
\hline Control & 32 & 71.11 & & & & \\
\hline
\end{tabular}


The result of independent $t$-test reveals that the obtained significant level was 0.001 . This value was lower than the accepted significant level 0.05 (sig. $0.001 \leq$ sig. 0.05). It meant that there was enough evidence to reject the null hypothesis and to accept the alternative hypothesis. Therefore, there was a significant difference in the ability in writing recount texts between the students taught by using picture series and those who were not taught by using picture series. In the other words, the students taught by using picture series had better ability in writing recount texts than those who were not taught by using picture series.

To get further information about the effectiveness of using picture series on the students' writing ability in writing recount texts, we investigated the significant difference per writing components by using independent $t$-test. The results of the independent $t$-test per writing components can be seen in Table 5.

Table5. Results of the Independent t-test per Writing Components

\begin{tabular}{|c|c|c|c|c|c|c|c|}
\hline Variables & Group & $\mathbf{N}$ & Mean & $\mathbf{T}$ & df & Sig. & Description \\
\hline \multirow{2}{*}{ Content } & Experimental & 32 & 22.69 & \multirow{2}{*}{7.032} & \multirow{2}{*}{62} & \multirow{2}{*}{0.000} & Significant \\
\hline & Control & 32 & 21.95 & & & & Difference \\
\hline \multirow{2}{*}{ Organization } & Experimental & 32 & 18.31 & \multirow{2}{*}{7.032} & \multirow{2}{*}{62} & \multirow{2}{*}{0.000} & Significant \\
\hline & Control & 32 & 17.32 & & & & Difference \\
\hline \multirow{2}{*}{ Vocabulary } & Experimental & 32 & 14.89 & \multirow{2}{*}{2.617} & \multirow{2}{*}{62} & \multirow{2}{*}{0.011} & Significant \\
\hline & Control & 32 & 14.03 & & & & Difference \\
\hline \multirow{2}{*}{ Grammar } & Experimental & 32 & 15.63 & \multirow{2}{*}{2.970} & \multirow{2}{*}{62} & \multirow{2}{*}{0.004} & Significant \\
\hline & Control & 32 & 14.23 & & & & Difference \\
\hline \multirow{2}{*}{ Mechanics } & Experimental & 32 & 3.69 & \multirow{2}{*}{0.714} & \multirow{2}{*}{62} & \multirow{2}{*}{0.478} & No Significant \\
\hline & Control & 32 & 3.59 & & & & Difference \\
\hline
\end{tabular}

Table 5 shows that the use of picture series was effective on the students' writing ability, especially in content, organization, vocabulary, and grammar components. However, in terms of mechanics component, there was no significant difference between the experimental and control groups.

The second hypothesis was about the effectiveness of the use of picture series across the students' learning styles on the students' ability in writing recount texts. To achieve this goal, we categorized the students into their learning styles by analyzing the learning styles questionnaire. The descriptive statistics data of the visual and auditory students in the experimental group is shown in Table 6.

Table6. Descriptive Statistics Data of the Visual and Auditory Students in the Experimental Group

\begin{tabular}{|l|l|l|}
\hline \multirow{2}{*}{ Descriptive Statistics } & \multicolumn{2}{|c|}{ Experimental Group } \\
\cline { 2 - 3 } & \multicolumn{1}{|c|}{ Visual } & \multicolumn{1}{|c|}{ Auditory } \\
\hline $\mathrm{N}$ & 24 & 72.25 \\
\hline Mean & 76.15 & 4.38 \\
\hline Standard Deviation & 4.12 & \multicolumn{1}{|c|}{} \\
\hline
\end{tabular}

It can be seen that the number of visual students was more than the number of auditory students. In the experimental group, the mean score of the visual students was 76.15 and the mean score of the auditory students was 72.25 .

The mean difference in the ability in writing recount text between the visual and auditory students in the experimental group was analyzed further by using independent $t$-test to see whether the mean difference was significant or not. Table 7 shows the independent $t$-test result between the visual and auditory students in the experimental group.

Table7. Results of the Independent t-test between the Visual and Auditory Students in the Experimental Group

\begin{tabular}{|l|l|l|l|l|l|l|l|}
\hline Group & Learning Style & N & Mean & T & df & Sig. & Description \\
\hline \multirow{2}{*}{ Experimental } & Visual & 24 & 76.15 & \multirow{2}{*}{2.284} & 30 & \multirow{2}{*}{0.030} & $\begin{array}{l}\text { Significant } \\
\text { Difference }\end{array}$ \\
\cline { 2 - 8 } & Auditory & 8 & 72.25 & & & \\
\hline
\end{tabular}

Based on Table 7, the obtained significant level in the experimental group was lower than the accepted significant level $(0.030 \leq 0.05)$. Hence, there was enough evidence to reject the null hypothesis and to accept the alternative hypothesis. It meant that there was a significant difference on the students' ability in writing recount texts between the visual and auditory students in the experimental group. In other words, the visual students had better ability in writing recount texts than the auditory students in the experimental group. 
Finally, we analyzed the results of the students' opinion questionnaire to support the findings in this study. The results of the students' opinion questionnaire are explained in Table 8.

Table8. The Summary of the Students' Opinion Questionnaire Results

\begin{tabular}{|c|c|c|c|c|c|c|}
\hline \multirow{2}{*}{$\begin{array}{l}\text { Sub- } \\
\text { Variable }\end{array}$} & \multirow{2}{*}{$\begin{array}{l}\text { Item } \\
\text { Number }\end{array}$} & \multicolumn{4}{|c|}{ Students' Response } & \multirow{2}{*}{$\begin{array}{l}\text { Average } \\
\text { Score }\end{array}$} \\
\hline & & $\begin{array}{l}\text { Strongly } \\
\text { Agree }\end{array}$ & Agree & Disagree & $\begin{array}{l}\text { Strongly } \\
\text { Disagree }\end{array}$ & \\
\hline \multirow{5}{*}{$\begin{array}{l}\text { Improving } \\
\text { Writing } \\
\text { Ability }\end{array}$} & 1 & $87.50 \%$ & $12.50 \%$ & - & - & \multirow{5}{*}{86.72} \\
\hline & 2 & $93.75 \%$ & $6.25 \%$ & - & - & \\
\hline & 3 & $68.75 \%$ & $31.25 \%$ & - & - & \\
\hline & 4 & $71.88 \%$ & $28.12 \%$ & - & - & \\
\hline & 5 & $50 \%$ & $34.38 \%$ & $15.62 \%$ & - & \\
\hline \multirow{3}{*}{$\begin{array}{l}\text { General } \\
\text { Perception }\end{array}$} & 6 & $93.75 \%$ & $6.25 \%$ & - & - & \multirow{3}{*}{88.02} \\
\hline & 7 & $65.63 \%$ & $34.37 \%$ & - & - & \\
\hline & 8 & $71.88 \%$ & $28.13 \%$ & - & - & \\
\hline
\end{tabular}

Table 8 reveals that most of the students answered "strongly agree" to all of the items of the questionnaire. It meant that most of the students strongly agree that the use of picture series could improve their writing ability and they had very positive perception towards the use of picture series in writing recount texts.

\section{DiscuSSION}

The main objective of this study was to find out the effectiveness of using picture series on the students' writing ability. The students of experimental group were taught by using picture series in writing recount text, meanwhile the control group were not taught by using picture series. Some literature and previous studies claimed that picture series were effective media to teach writing. Moreover, the statistical computation in research findings revealed that the use of picture series significantly affected the students' ability in writing recount texts. The obtained significant level was lower than the accepted significant level (sig. $0.001 \leq$ sig. 0.05). It meant that there was enough evidence to reject the null hypothesis and to accept the alternative hypothesis. Therefore, there was a significant difference in the ability in writing recount texts between the students taught by using picture series than those who were not taught by using picture series. In the other words, the students taught by using picture series had better ability in writing recount text than those who were not taught by using picture series. This finding was in line with the previous studies. Mudassir (2014) found out that the use of picture series was effective in teaching recount texts, especially in generating and organizing students' ideas.

The effectiveness of the use of picture series was analyzed further by calculating the significant difference among the five writing components in terms of content, organization, vocabulary, grammar, and mechanics. The results of posttest showed that there were significant differences on content, organization, vocabulary, and grammar component of the students' recount text writing. This finding was in line with Wright (1989) who stated that pictures had a powerful contribution to both the content and the process of language learning. In the same vein, Reid (1995) stated that students would write easily if the teachers use audio or visual media in triggering them to begin to write. This finding is also related Raimes' (1983) statement that a set of pictures provided material that gives guidance on vocabulary, sentence structure, and organization. Nirmala (2013) in her study concluded that picture series provide information of which event comes first and which one comes next. At last, this finding was also in line with Krčelić and Matijević's (2015) statement that pictures as visual media could enhance students' vocabulary and grammar skills because the simultaneous visual input provided by visual tools facilitated both teaching and learning foreign languages. This finding was also in line with Mudassir's (2014) study. She found that picture series did not affect the students' mechanics in writing. The reason was that the students paid more attention to the use of grammar instead of mechanics.

In general, this finding enriched the existing theory which claims that pictures series were effective media in teaching writing. As stated by Wright (1989), pictures had an important role in language learning since pictures contribute to the context, structure, vocabulary, function, and skill in which the language is being used. In addition, the use of picture series was appropriate as media to teach writing, especially dealing with recount text (Fachrurrazy, 2012). Pictures are valuable resources in the teaching and learning process since they provide a shared experience in the classroom. 
Furthermore, picture series showed some actions or events in a chronological order. By knowing the sequence of events, the students could generate and organize their ideas better than without using picture series.

However, there was a challenge to prove whether the use of picture matched with one of the students' learning styles, namely visual students. The effect of picture series on students' learning styles was investigated to see the effectiveness. The result of the statistical computation by means of SPSS 20.0 showed that there was a significant difference on students' ability in writing recount texts between the visual and auditory students who were taught by using picture series $(0.030 \leq 0.05)$. This finding was relevant with Reid (1995) who stated that a mismatch between teaching and learning styles cause learning failure, frustration, and demotivation. In this study, visual students were closely related with the use of picture series since picture series were visual media. Visual students tend to have an ability to create and to memorize by visualizing something, especially in the form of colors, images, and pictures (Gilakjani \& Ahmadi, 2011; Ligthbown \& Spada,1993). These students will be able to learn something after reading the instruction, watching someone else does it first, and studying charts, drawing, or other graphic information. That is why, in this study the visual students achieved better in the experimental group since they learnt by using their preferred way. The use of picture series was compatible with the way of learning of the visual students.

Apart from the main research objectives, we analyzed the results of the students' opinion questionnaire. In general, the students had very positive opinion towards the use of picture series as media in writing recount texts. Most of the students felt that picture series helped them in writing recount text in the terms of content, organization, vocabulary, grammar, and mechanics. Moreover, most of the students also felt that learning to write recount texts by using picture series was interesting and could motivate them to learn writing. These findings were in line with literature which shows that the use of picture series can motivate the students in writing (Harmer, 2004; Raimes, 1983; Wright, 1989). According to these researchers, pictures make the students pay attention and take part in the teaching and learning process. Therefore, most of the students strongly agreed to continue the use of picture series in learning to write recount texts.

This study was carefully prepared and conducted, but we realized that it had some limitations and shortcomings. First of all, this study was conducted in two classes for eight meetings. Eight meetings were not enough for us to give the appropriate treatment by using picture series. It would be better if it was done in a longer time. Second, there was one type of learning style which was not calculated in this study, namely kinaesthetic learning style. It would be better if it was included in the future research. At last, it was not easy for us to choose the appropriate picture series used in the treatment. It would be better if there was a media validation before conducting research on the use of instructional media.

\section{Conclusion}

The findings of this study showed that the students taught by using picture series achieved significantly better scores of writing than those who were not taught by using picture series especially in terms of content, organization, vocabulary, and grammar components. It could be concluded that picture series were effective towards the students' ability in writing recount texts. In addition, the students' opinion questionnaire results revealed that the use of picture series could improve their ability in writing recount texts, including most of the components. Hence, the use of picture series made the students feel motivated and interested in the teaching and learning of writing. More importantly, the students wanted to continue the use of picture series in writing recount text activities.

Moreover, the findings also revealed that there was a significant difference on the students' ability in writing recount texts between the visual and auditory students who were taught by using picture series. It can be said that picture series as one of visual media are appropriate for visual students since the visual students learn something by visualizing it. In other words, there was a match between instructional media and the students' learning styles in affecting the students' writing ability.

It is suggested to other EFL teachers to take these findings as the consideration in improving the students' writing ability. They are also suggested to be creative and selective in choosing the appropriate picture series used in teaching writing. It is also necessary for the teachers to combine the use of picture series with the appropriate teaching strategy in enhancing students' writing ability. Meanwhile, the findings of this research can be used for the future researchers as a reference to 
conduct further research using different text types, instructional media, learning styles, grade, and level of education in the teaching and learning of writing.

\section{REFERENCES}

Agustien, H. I. R., Anugerahwati, M. and Wachidah, S. Materi pelatihan terintegrasi bahasa Inggris [Materials for integrated training] Jakarta: Depdiknas. 2004.

Asrifan, A. The use of pictures story in improving students' ability to write narrative composition. International Journal of Language and Linguistics, (Online), 3(4), 244-251, 2015. Retreived October 23, 2016, from http://article.sciencepublishinggroup.com.

Brown, H. D. Teaching by principles: An interactive approach to language pedagogy ( $3^{\text {rd }}$ ed.). New York: Pearson Education. 2007.

Celce-Murcia, M. Teaching English as a second or foreign language ( $3^{\text {rd }}$ ed.). New York: Dewey Publishing Services. 2001.

Chee, T. S. and Wong, A. F. L. Teaching and learning with technology: An Asia-Pacific perspective. Prentice Hall: Pearson Education Asia. 2003.

DePorter, B., Reardon, M. and Singer-Nourie, S. Quantum teaching. Translator Ary Nilandari. Bandung: Kaifa. 1999.

Fachrurrazy. Teaching English as a foreign language for teachers in Indonesia. Malang: State University of Malang Press. 2012.

Gilakjani, A. P. and Ahmadi, S. M. The effect of visual, auditory, and kinaesthetic styles on language teaching. International Conference on Social Science and Humanity, 4(2): 469-471, 2011. Retreived August 13, 2016, from http://www.ipedr.com

Guitterez, K. G. C., Puello, M. N. and Galvis, L. A. P. Using picture series technique to enhance narrative writing among ninth grade students at Institución Educativa Simón Araujo. ELT Canadian Center of Science and Education, 8(5), 45-71, 2015. Retrieved September 17, 2016, from http://files.eric.ed.gov Harmer, J. How to teach writing. Essex, UK: Pearson Education. 2004.

Jacobs, H. L., Zinkgraf, S. A., Wormuth, D. R., Hartfiel, V. F. and Hughey, J. B. Testing ESL composition: A practical approach. Rowley, Massachusetts: Newbury House Publisher, Inc. 1981.

Kemdikbud. Peraturan menteri pendidikan dan kebudayaan republik Indonesia nomor 21 tahun 2016 tentang standar isi pendidikan dasar dan menengah [The rule of the minister of education and culture of the republic of Indonesia No 21/2016 on content standard for basic and secondary education]. Jakarta: Kementerian Pendidikan dan Kebudayaan. 2015.

Krčelić, P. and Matijević, A. S. A picture and a thousand words: Visual tools in ELT. International Language Conference on the Importance of Learning Professional Foreign Languages for Communication between Cultures, 110-114, 2015. Retrieved September 6, 2016, from https://bib.irb.hr

Mudassir, Y. S. The effectiveness of using picture series on students' ability in writing a recount text at junior high school. Unpublished Masters Thesis. Malang: State University of Malang. 2014.

Nirmala, Y. Teaching writing using picture stories as tools at the high school level: Yhe movement from other regulation to self regulation. Dissertation. Hyderabad: The English and Foreign Languages University. 2013. Retrieved August 17, 2016, from https://languageinindia.com

Pertiwi, L. A. J. Documentary films, process genre approach, and writing ability: An action research. Unpublished Masters Thesis. Malang: State University of Malang. 2016.

Raimes, A. Techniques in teaching writing. Oxford: Oxford University Press. 1983.

Reid, J. M. Learning styles in ESL/EFL classroom. Boston: Heinle \& Heinle. 1995.

Samjaya, W. Media komunikasi pembelajaran. Jakarta: Kencana Prenada Media Group. 2012.

Smaldino, S. E., Lowther, D. L. and Russel J. D. Instructional technology and media for learning $\left(9^{\text {th }}\right.$ ed.). New Jersey: Pearson Prentice Hall. 2009.

Wright, A. Picture for language learning. New York: Cambridge University Press. 1989.

Yuliarsih. The effectiveness of using picture series to teach writing in SMPN 1 Waru Pamekasan. Kabilah, 1(1), 39-52, 2016. Retrieved August 17, 2016, from http://ejournal.kopertais4.or.id 


\section{AUTHORS' BIOGRAPHY}

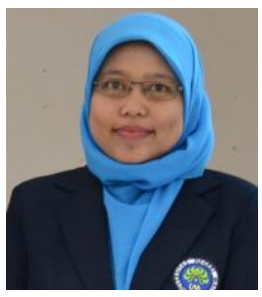

Rahayu Hesthi Wening, is an English teacher of Junior High School 2 Kawunganten, Cilacap, Central Java, Indonesia. She got her undergraduate program in English Language Teaching at Universitas Negeri Yogyakarta, Indonesia (2006). In 2015 , she pursued her study at graduate program in the same field at Universitas Negeri Malang, East Java, Indonesia.

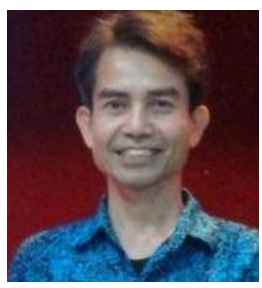

Bambang Yudi Cahyono, is a Professor in Applied Linguistics at Universitas Negeri Malang, East Java, Indonesia. He earned his MA from Condordia University, Montreal, Canada (2000) and PhD from the University of Melbourne, Australia (2006). His research interest includes Second Language Writing, English Teachers' Professional Development, and the Use of ICT in ELT.

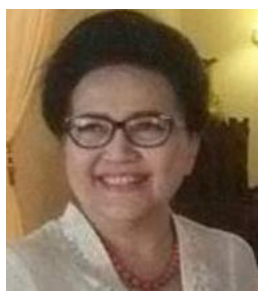

Emalia Iragiliati, is a lecturer at Universitas Negeri Malang, East Java, Indonesia. She got her Master (1991) and Doctoral (2005) degree of English Language Teaching at Universitas Negeri Malang. Her expertise covers sociolinguistics, pragmatics, CCU, ESP, Material Development, and Teaching English in International School. 